\title{
Anxiety and Sleep Quality in Dental Students at a Private Brazilian University
}

\author{
Amanda V. Machado, Camila O. Castro, Carlos R. Botelho Filho, \\ Carolina D. Bruzamolin, Rafaela Scariot, Eduardo Pizzatto and \\ Marilisa C. L. Gabardo
}

School of Health Sciences, Universidade Positivo, Curitiba 80280-330, Brazil

Received 21 December, 2018/Accepted for publication 12 March, 2019

Published Online in J-STAGE 20 February, 2020

\begin{abstract}
The aim of this cross-sectional study was to evaluate the impact of anxiety and quality of sleep on quality of life (QOL) in undergraduate dental students. A total of 141 students were enrolled. All were required to answer the following questionnaires: the State-Trait Anxiety Inventory (STAI) subscale state (S) (STAI-S); the Sleep Assessment Questionnaire (SAQ); and the simplified World Health Organization Quality of Life survey (WHO QOL-bref). The statistical analysis included univariate and bivariate analyses and Poisson regressions. The mean age of the participants was $22.9(\mathrm{SD}=5.2)$ years; $81.6 \%$ were women, and $37.6 \%$ studied during the morning shift. The mean STAI-S score was 50.3 $(\mathrm{SD}=9.4)$. Sleep problems, classified as "always" or "frequently", were reported by $11.3 \%$ and $18.4 \%$ of the sample, respectively. Quality of life had a mean score of $13.2(\mathrm{SD}=2.0)$. The STAI-S and SAQ scores showed a significant association with all WHOQOL-bref dimensions $(\mathrm{p}<0.05)$. Analyses performed using multivariate regression and the highest STAI-S score $(\mathrm{RR}=1.46,95 \% \mathrm{CI}=1.03-2.06)$ and SAQ $(\mathrm{RR}=1.39,95 \% \mathrm{CI}=1.02-1.90)$ demonstrated significant sleep problems, even when other variables were controlled to prevent confounding biases. In conclusion, the dental students evaluated showed high levels of anxiety and sleep disorders impacting on QOL.
\end{abstract}

Key words: Anxiety — Cross-sectional study — Higher education — Sleep disorders

\section{Introduction}

One of the common problems faced by people throughout life is anxiety. The prevalence of anxiety is higher in students than in the general population ${ }^{22}$. Many students reported academic study to be stressful ${ }^{3,20)}$.
Time demands, the pressure to learn, the volume of information to be assimilated, the expectation of a high income, the lack of time for social and physical activities, poor diet, and a lack of experience of dealing with sick people and death have been identified as potential factors in the onset of depressive 
symptoms in the learning environment ${ }^{15,38,39)}$.

A number of academic scenarios have been demonstrated as being potentially contributory to the development of stress. These include academic assessments, deadlines, the performance and presentation of papers, criticism, difficulties in understanding professors' explanations, and extra-curricular activities $^{39)}$. In addition, adaptation to new situations, such as the city environment, housing, and distance from the family, are also known stressors ${ }^{4}$.

The student population has been identified as being psychologically vulnerable, with women especially so ${ }^{11,15,21-23)}$. One crossnational study encompassing 19 universities in 8 countries revealed that $42.9 \%$ of the sample reported at least one mental disor$\operatorname{der}^{1}$. The prevalence of undergraduates in Brazil with some type of psychological disorder is high, reaching $50 \%{ }^{27}$. One systematic review revealed that dental students also suffer from stress ${ }^{17}$.

According to the "Fórum Nacional de PróReitores de Assuntos Comunitários e Estudantis" (National Forum of Pro-Rectors of Community and Student Affairs) in 2011, 47.7\% of students reported various forms of psychiatric disorder ${ }^{3)}$. In 2014, this value, evaluated as "emotional difficulties that may have interfered in their academic life in the last 12 months", reached $79.8 \%$, which is extremely high $^{4)}$. This same study revealed that $32 \%$ had insomnia, and almost $60 \%$ had anxiety.

The State-Trait Anxiety Inventory (STAI) was developed to investigate anxiety, and was first introduced by Spielberg et al. in $1970^{43)}$. Indicated for the analysis of an individual's general and momentary states of anxiety, it has been used with university students ${ }^{11)}$.

Sleep alterations are also frequently found in university students, commonly presenting as irregular sleep. Moreover, evidence supports an association between such altered sleep patterns and anxiety levels in the life of the university student ${ }^{36}$. In addition, overall sleep quality has been associated with mental health $^{322}$. The Sleep Assessment Questionnaire $(\mathrm{SAQ})$ is an instrument developed to evaluate this particular correlation ${ }^{13)}$.

A relationship has been suggested among sleep disturbances, anxiety, and quality of life (QOL) in young people ${ }^{34,45)}$, and particularly in university students ${ }^{41}$. Quality of life is a multidimensional and subjective concept, involving physical, psychological, and social perceptions ${ }^{47)}$. In order to develop an instrument that captured this subjectivity, the World Health Organization (WHO) proposed the WHOQOL questionnaire. The initial version consisted of 100 questions ${ }^{18)}$. This was later simplified to 26 questions (WHOQOLbref) ${ }^{46)}$. Quality of life measured by the WHOQOL-bref showed an association with sleep disturbances ${ }^{5,29,40)}$.

Some studies have reported that this observed association between anxiety and sleep disorders directly affects a student's QOL, noting that it is therefore necessary to determine suitable support mechanisms for students aimed at helping them cope with the types of challenging situation that they will encounter during the course of their training $^{5,17}$. In light of the above, the aim of this study was to evaluate the impact of anxiety and quality of sleep on QOL in undergraduate students of dentistry at Universidade Positivo, Curitiba, Brazil.

\section{Materials and Methods}

This study was approved by the Ethics Committee in Research with Human Beings of Universidade Positivo (register no. 1,678,805), and the procedures used met the protocols stipulated in the ethical guidelines set out in the Declaration of Helsinki.

\section{Sample selection}

This was an observational, cross-sectional study employing quantitative analysis. A total of 141 full-time students at the Faculty of Dentistry at Universidade Positivo (from among a total of 152) were enrolled in the study. All were aged 18 years or over; both sexes and students working both shifts (day or night) were included. Recruitment was carried out 
in March 2017.

All the study participants signed a Free and Informed Consent Form. Students who reported having an impediment at the time of completing questionnaires were excluded.

\section{Data collection instruments}

Two previously validated questionnaires were used to assess anxiety and quality of sleep. They were applied via Google ${ }^{\circledast}$. The STAI was used to evaluate anxiety. This instrument has a version translated and adapted for Brazil $^{10)}$. This is a self-assessment questionnaire consisting of two subscales: Trait STAI and State STAI (STAI-S). The anxiety trait refers to how the individual usually feels, while the state of anxiety reflects a transient situation; that is, the behavior of the individual at a given moment ${ }^{12)}$.

The present study used the STAI, which comprises 20 items, with each question scored on a 4-point Likert scale, ranging from 1 (absolutely not) to 4 (very much). The response is based on how the participant feels "now, at this time". The total score is obtained by the sum of the scores, which can range from 20 to $80^{10,43)}$. For the purpose of analysis, the total gross score was divided into quartiles.

The SAQ was used to evaluate quality of sleep. This consists of 17 items that evaluate sleep experience over the last 30 days ${ }^{13)}$. Each item is rated on a 5-point scale, where 0 represents "never or never"; 1 represents "rarely"; 2 represents "sometimes"; 3 represents "often"; and 4 represents "always". The total score was calculated as the sum of the values of all items; division into quartiles was also performed.

The original WHOQOL-bref, which comprised 26 questions ${ }^{46)}$, was adapted and validated for the Portuguese language of Brazil ${ }^{19)}$, which was considered as a dependent variable. This version contains 2 general questions on QOL, while each of the remaining 24 is representative of a particular facet thereof. In this way, each domain (physical, psychological, personal relations, and the environment) may be explored ${ }^{46)}$. The responses fol- low the Likert-type pattern: "very bad to very good" (rating scale); "very unsatisfied to very satisfied" (rating scale); "nothing to extremely" (intensity scale); "nothing to completely" (scale of capacity); and "never to always" (frequency scale). Each domain consists of questions that correlate with answer scores ranging from 1 to 5 . The higher the score, the better the perception ${ }^{18}$. The total score for each individual was accounted for and dichotomized by the median as better (WHO QOL $>14$ ) or worse (WHOQOL $\leq 14)$. The dimensions and their gross scores were also considered in the analysis.

The independent variables collected were as follows: age (in years), which was dichotomized by the median ( $\leq 21$ and $>21)$; sex (male or female); years of study (1st, 2nd-3rd, and 4 th -5 th); and shift (morning or night).

\section{Statistical analysis}

The data were initially subjected to descriptive analysis. For the evaluation of STAI-S and $\mathrm{SAQ}$, the variables were divided into 4 classes according to the quartiles. The Kruskal-Wallis and Mann-Whitney $U$ tests were performed for comparisons between demographic and school variables, and for the WHOQOL (gross score) domains. The Poisson regression model was used in bivariate and multivariate analyses in order to determine associations between the outcome (better or worse QOL) and the independent variables. For inclusion in this model, p-values of $<0.20$ from the bivariate analyses were considered.

The statistical analysis was performed using the Statistical Package for the Social Sciences (IBM $^{\circledast}$ SPSS $^{\circledast}$, Armonk, USA), version 21.0. Significance was set at $\mathrm{p}<0.05$.

\section{Results}

The response rate was $92.8 \%$. The mean age was $22.9(\mathrm{SD}=5.2)$ years, with women predominating (81.6\%). Students working the morning shift occupied the highest percentage $(62.4 \%)$.

When asked whether they felt anxiety, 
Table 1 Association between demographic and school variables, anxiety, and sleep quality among students at a private Brazilian university.

\begin{tabular}{|c|c|c|c|c|c|c|c|c|c|c|}
\hline \multirow{2}{*}{ Variables } & \multicolumn{5}{|c|}{ STAI-S } & \multicolumn{5}{|c|}{ SAQ } \\
\hline & $\begin{array}{c}31-42.5 \\
\mathrm{n}(\%)\end{array}$ & $\begin{array}{c}42.6-49 \\
\mathrm{n}(\%)\end{array}$ & $\begin{array}{c}49.1-56.5 \\
\mathrm{n}(\%)\end{array}$ & $\begin{array}{c}56.6-76 \\
\text { n }(\%)\end{array}$ & p-value* & $\begin{array}{l}27-38 \\
\mathrm{n}(\%)\end{array}$ & $\begin{array}{c}38.1-45 \\
\mathrm{n}(\%)\end{array}$ & $\begin{array}{c}45.1-52 \\
\mathrm{n}(\%)\end{array}$ & $\begin{array}{c}52.1-64 \\
\mathrm{n}(\%)\end{array}$ & $\mathrm{p}$-value \\
\hline \multicolumn{11}{|l|}{ Age } \\
\hline$\leq 21$ & $\begin{array}{c}19 \\
(54.3)\end{array}$ & $\begin{array}{c}26 \\
(66.7)\end{array}$ & $\begin{array}{c}15 \\
(46.9)\end{array}$ & $\begin{array}{c}16 \\
(45.7)\end{array}$ & 0.247 & $\begin{array}{c}20 \\
(55.6)\end{array}$ & $\begin{array}{c}20 \\
(55.6)\end{array}$ & $\begin{array}{c}21 \\
(58.3)\end{array}$ & $\begin{array}{c}15 \\
(45.5)\end{array}$ & 0.726 \\
\hline$>21$ & $\begin{array}{c}16 \\
(45.7)\end{array}$ & $\begin{array}{c}13 \\
(33.3)\end{array}$ & $\begin{array}{c}17 \\
(53.1)\end{array}$ & $\begin{array}{c}19 \\
(54.3)\end{array}$ & & $\begin{array}{c}16 \\
(44.4)\end{array}$ & $\begin{array}{c}16 \\
(44.4)\end{array}$ & $\begin{array}{c}15 \\
(41.7)\end{array}$ & $\begin{array}{c}18 \\
(54.5)\end{array}$ & \\
\hline \multicolumn{11}{|l|}{ Sex } \\
\hline Male & $\begin{array}{c}6 \\
(17.1)\end{array}$ & $\begin{array}{c}8 \\
(20.5)\end{array}$ & $\begin{array}{c}8 \\
(25.0)\end{array}$ & $\begin{array}{c}4 \\
(11.4)\end{array}$ & 0.530 & $\begin{array}{c}10 \\
(27.8)\end{array}$ & $\begin{array}{c}4 \\
(11.1)\end{array}$ & $\begin{array}{c}6 \\
(16.7)\end{array}$ & $\begin{array}{c}6 \\
(18.2)\end{array}$ & 0.327 \\
\hline Female & $\begin{array}{c}29 \\
(82.9)\end{array}$ & $\begin{array}{c}31 \\
(79.5)\end{array}$ & $\begin{array}{c}24 \\
(75.0)\end{array}$ & $\begin{array}{c}31 \\
(88.6)\end{array}$ & & $\begin{array}{c}26 \\
(72.2)\end{array}$ & $\begin{array}{c}32 \\
(88.9)\end{array}$ & $\begin{array}{c}30 \\
(83.3)\end{array}$ & $\begin{array}{c}27 \\
(81.8)\end{array}$ & \\
\hline \multicolumn{11}{|l|}{ Years of study } \\
\hline 2nd-3rd & $\begin{array}{c}26 \\
(74.3)^{\mathrm{a}}\end{array}$ & $\begin{array}{c}25 \\
(64.1)^{\mathrm{a}}\end{array}$ & $\begin{array}{c}12 \\
(37.5)^{\mathrm{a}}\end{array}$ & $\begin{array}{c}15 \\
(42.9)^{\mathrm{a}}\end{array}$ & & $\begin{array}{c}20 \\
(55.6)\end{array}$ & $\begin{array}{c}22 \\
(61.1)\end{array}$ & $\begin{array}{c}17 \\
(47.2)\end{array}$ & $\begin{array}{c}19 \\
(57.6)\end{array}$ & \\
\hline $1 \mathrm{st}$ & $\begin{array}{c}3 \\
(8.6)^{\mathrm{a}, \mathrm{b}}\end{array}$ & $\begin{array}{c}4 \\
(10.3)^{\mathrm{a}}\end{array}$ & $\begin{array}{c}4 \\
(12.5)^{\mathrm{a}, \mathrm{b}}\end{array}$ & $\begin{array}{c}5 \\
(14.3)^{\mathrm{a}}\end{array}$ & 0.039 & $\begin{array}{c}3 \\
(8.3)\end{array}$ & $\begin{array}{c}4 \\
(11.1)\end{array}$ & $\begin{array}{c}5 \\
(13.9)\end{array}$ & $\begin{array}{c}4 \\
(12.1)\end{array}$ & 0.917 \\
\hline 4 th-5th & $\begin{array}{c}6 \\
(17.1)^{\mathrm{b}}\end{array}$ & $\begin{array}{c}10 \\
(25.6)^{\mathrm{a}}\end{array}$ & $\begin{array}{c}16 \\
(50.0)^{\mathrm{b}}\end{array}$ & $\begin{array}{c}15 \\
(42.9)^{\mathrm{a}}\end{array}$ & & $\begin{array}{c}13 \\
(36.1)\end{array}$ & $\begin{array}{c}10 \\
(27.8)\end{array}$ & $\begin{array}{c}14 \\
(38.9)\end{array}$ & $\begin{array}{c}10 \\
(30.3)\end{array}$ & \\
\hline \multicolumn{11}{|l|}{ Shift } \\
\hline Morning & $\begin{array}{c}18 \\
(51.4)\end{array}$ & $\begin{array}{c}30 \\
(76.9)\end{array}$ & $\begin{array}{c}20 \\
(62.5)\end{array}$ & $\begin{array}{c}20 \\
(57.1)\end{array}$ & 0.126 & $\begin{array}{c}28 \\
(77.8)\end{array}$ & $\begin{array}{c}17 \\
(47.2)\end{array}$ & $\begin{array}{c}21 \\
(58.3)\end{array}$ & $\begin{array}{c}22 \\
(66.7)\end{array}$ & 0.053 \\
\hline Night & $\begin{array}{c}17 \\
(48.6)\end{array}$ & $\begin{array}{c}9 \\
(23.1)\end{array}$ & $\begin{array}{c}12 \\
(37.5)\end{array}$ & $\begin{array}{c}15 \\
(42.9)\end{array}$ & & $\begin{array}{c}8 \\
(22.2)\end{array}$ & $\begin{array}{c}19 \\
(52.8)\end{array}$ & $\begin{array}{c}15 \\
(41.7)\end{array}$ & $\begin{array}{c}11 \\
(33.3)\end{array}$ & \\
\hline
\end{tabular}

Note: Kruskal-Wallis and Mann-Whitney $U$ tests. Bold values and different letters indicate statistically significant difference $(p<0.05)$.

$37.6 \%$ of the students indicated "extremely", $31.9 \%$ "rather", and $24.8 \%$ "a little". The mean STAI-S was $50.3(\mathrm{SD}=9.4)$.

Concerning sleep disorders, $11.3 \%$ responded "always", 18.4\% "frequently", and 34.0\% "sometimes". A total of $10.6 \%$ of the students reported "always" when asked if they used medication to achieve better sleep.

The mean crude score and standard deviation of WHOQOL-bref were 13.2 ( $\mathrm{SD}=2.0)$. The dimensions and their respective mean values were: physical D1 (12.6), psychological D2 (13.3), social relations D3 (14.1), and environment (13.2).

Table 1 shows the associations between the demographic and school variables, as evaluated using the STAI-S and SAQ outcomes. Students in the first and last years showed more anxiety than those of the 2nd-3rd years $(p<0.05)$. Regarding quality of sleep, there was no significant difference between the morning and night shifts $(p=0.053)$. This result was considered borderline.

Table 2 shows the results of association tests between the WHOQOL-bref domains and other variables. Students in the first and last year showed a significant difference $(p=0.038)$ in the psychological dimension. The variable, "global quality of life and general health perception", was also significantly associated with 
Table 2 Association between WHOQOL-bref domains and demographic, school, anxiety, and sleep variables among students at a private Brazilian university.

\begin{tabular}{|c|c|c|c|c|c|}
\hline Variables & $\begin{array}{l}\text { D1 median } \\
\text { (min.-max.) }\end{array}$ & $\begin{array}{l}\text { D2 median } \\
\text { (min.-max.) }\end{array}$ & $\begin{array}{l}\text { D3 median } \\
\text { (min.-max.) }\end{array}$ & $\begin{array}{l}\text { D4 median } \\
\text { (min.-max.) }\end{array}$ & $\begin{array}{l}\text { Global quality of } \\
\text { life and general } \\
\text { health perception }\end{array}$ \\
\hline \multicolumn{6}{|l|}{ Age } \\
\hline$\leq 21$ & $13(7-18)$ & $13(7-18)$ & $15(5-20)$ & $14(8-18)$ & $16(8-20)$ \\
\hline$>21$ & $12(5-18)$ & $14(7-19)$ & $15(4-20)$ & $13(6-18)$ & $16(6-20)$ \\
\hline p-value* & 0.859 & 0.917 & 0.855 & 0.056 & 0.221 \\
\hline \multicolumn{6}{|l|}{$\operatorname{Sex}$} \\
\hline Male & $14(8-17)$ & $15(9-19)$ & $15(8-20)$ & $14(8-18)$ & $16(6-20)$ \\
\hline Female & $13(5-18)$ & $13(7-18)$ & $15(4-20)$ & $13(6-18)$ & $16(6-20)$ \\
\hline p-value* & 0.118 & 0.093 & 0.441 & 0.515 & 0.510 \\
\hline \multicolumn{6}{|l|}{ Years of study } \\
\hline 2nd-3rd & $13(5-18)$ & $14(7-18)^{\mathrm{b}}$ & $15(4-20)$ & $14(6-18)$ & $16(6-20)$ \\
\hline $1 \mathrm{st}$ & $13(9-15)$ & $12.5(9-19)^{\mathrm{a}}$ & $15.5(5-20)$ & $13.5(9-18)$ & $15(8-18)$ \\
\hline 4 th-5th & $13(6-17)$ & $13(7-17)^{\mathrm{a}}$ & $15(7-20)$ & $13(6-18)$ & $16(6-20)$ \\
\hline p-value* & 0.468 & 0.038 & 0.962 & 0.689 & 0.516 \\
\hline \multicolumn{6}{|l|}{ Shift } \\
\hline Morning & $13(6-17)$ & $14(7-17)$ & $15(5-20)$ & $14(6-18)$ & $16(6-20)$ \\
\hline Night & $13(5-18)$ & $13(7-19)$ & $15(4-20)$ & $13(6-18)$ & $14(6-20)$ \\
\hline p-value* & 0.405 & 0.231 & 0.753 & $<0.001$ & 0.007 \\
\hline \multicolumn{6}{|c|}{ STAI-S (quartiles) } \\
\hline $31-42.5$ & $15(10-18)^{\mathrm{a}}$ & $15(12-19)^{\mathrm{a}}$ & $16(9-20)^{\mathrm{a}}$ & $14(9-18)^{\mathrm{a}}$ & $16(12-20)^{\mathrm{a}}$ \\
\hline $42.6-49$ & $13(9-18)^{\mathrm{ab}}$ & $14(10-17)^{\mathrm{ab}}$ & $15(5-20)^{\mathrm{a}}$ & $14(9-18)^{\mathrm{ab}}$ & $16(10-20)^{\mathrm{a}}$ \\
\hline $49.1-56.5$ & $13.5(9-17)^{\mathrm{b}}$ & $13(8-16)^{\mathrm{b}}$ & $15(7-20)^{\mathrm{a}}$ & $13(8-18)^{\mathrm{b}}$ & $16(6-20)^{\mathrm{a}}$ \\
\hline $56.6-76$ & $10(5-14)^{\mathrm{c}}$ & $11(7-15)^{\mathrm{c}}$ & $12(4-16)^{\mathrm{b}}$ & $12(6-17)^{\mathrm{c}}$ & $14(6-18)^{\mathrm{b}}$ \\
\hline p-value** & $<\mathbf{0 . 0 0 1}$ & $<0.001$ & $<0.001$ & $<0.001$ & $<0.001$ \\
\hline \multicolumn{6}{|l|}{ SAQ (quartiles) } \\
\hline $27-38$ & $14(11-18)^{\mathrm{a}}$ & $15(10-18)^{\mathrm{a}}$ & $15(5-20)^{\mathrm{a}}$ & $14(9-18)^{\mathrm{a}}$ & $16(12-20)^{\mathrm{a}}$ \\
\hline $38.1-45$ & $14(10-18)^{\mathrm{a}}$ & $14.5(8-19)^{\mathrm{ab}}$ & $15(8-20)^{\mathrm{a}}$ & $14(9-17)^{\mathrm{a}}$ & $16(10-20)^{\mathrm{a}}$ \\
\hline $45.1-52$ & $12(7-15)^{\mathrm{b}}$ & $13(8-16)^{\mathrm{b}}$ & $15(7-19)^{\mathrm{ab}}$ & $13(8-18)^{\mathrm{a}}$ & $16(6-18)^{\mathrm{a}}$ \\
\hline $52.1-64$ & $10(5-15)^{\mathrm{c}}$ & $11(7-17)^{\mathrm{c}}$ & $13(4-20)^{\mathrm{b}}$ & $11(6-17)^{\mathrm{b}}$ & $12(6-16)^{\mathrm{b}}$ \\
\hline p-value* & $<0.001$ & $<0.001$ & 0.011 & 0.002 & $<0.001$ \\
\hline
\end{tabular}

Note: Kruskal-Wallis and Mann-Whitney $U$ tests. Bold values and different letters indicate statistically significant difference $(\mathrm{p}<0.05)$.

D1: physical domain; D2: psychological domain; D3: personal relations; D4: environment.

shift $(\mathrm{p}=0.007)$.

Anxiety (STAI-S) and sleep problems with all dimensions analyzed. 
Table 3 shows the results of the bivariate and multivariate analyses, and indicates means of better and worse QOL outcomes in association with the independent variables surveyed.

The independent variables in STAI-S and SAQ showed a significant correlation with the dependent variables, even after adjustment, which indicates that higher values in either are associated with worse QOL.

\section{Discussion}

The aim of this study was to evaluate the impact of demographic, school, anxiety, and quality of sleep quality on self-perception of QOL in students undertaking a graduate dentistry course at a private Brazilian university. The analyses showed that students who were more anxious and had worse quality of sleep scores reported poorer QOL.

Earlier studies identified a number of factors as being contributory to an increase in depressive symptoms among students, and these included excessive pressure to study and assimilate large volumes of information, a lack of time, and poor nutrition ${ }^{4,15,38,39)}$. One systematic review revealed that stress in dental students was mainly due to the demanding nature of the training involved, something that differentiated them from students undertaking other courses ${ }^{17)}$.

The vulnerability of university students is a reality $^{3,4)}$, and this has been reported to be especially the case in women ${ }^{11,15,21-23)}$. The results of the present study support this earlier finding, with women, who comprised the majority of the study participants, showing higher levels of anxiety.

Dentistry students showed higher levels of anxiety than students undertaking other health-related courses ${ }^{42)}$. One study showed that dental academics showed high levels of anxiety and depression, as well as more difficulties in interpersonal relationships ${ }^{7}$. The present study also found a marked prevalence of students reporting high levels of anxiety.

Poor sleep quality among university stu- dents is a relevant problem ${ }^{24)}$. In the present study, almost $30 \%$ of the sample reported some form of sleep disorder, ranging from "always" to "frequently". Earlier studies on medical students reported a prevalence of sleep disorders of $42.3 \%{ }^{26)}$ and $38.9 \%^{311}$.

One study noted that excessive use of technology has an impact on quality of sleep due to the marked changes in lifestyle it encourages, with this being especially evident in the academic environment ${ }^{44}$. Harmful behaviors such as irregular bedtimes, prolonged naps during the day, alcohol use, and studying in bed can also have a negative impact on sleep ${ }^{24)}$.

Pascotto et al. reported that $10.3 \%$ of students used medication to regulate sleep ${ }^{35)}$. This finding was supported by that of the present study, with $10.6 \%$ of the study participants answering "always" to use of sleep medication. This value was higher than that observed in medical students in an earlier study, where only $8.6 \%$ reported using sleep medication ${ }^{16)}$. This highlights the seriousness of this problem, as many dental students appear to selfmedicate without seeking proper medical advice.

The STAI was used in the present study as it has already been used in investigations targeting university students ${ }^{11}$. The subscale STAI-S evaluates the behavior of an individual at a given moment ${ }^{43)}$. The psychometric properties of the STAI were considered adequate in a recent study ${ }^{33)}$. The minimum value for the sum of the scores with this particular instrument is 20. In the present study, however, the minimum score was 31 . One earlier study considered that values of 31 to 49 indicated moderate anxiety ${ }^{377}$. This suggests that there were no cases of only mild anxiety in the present study. This justifies the methodological choice of dividing this variable into quartiles, in addition to the fact that its distribution allowed this consideration.

The SAQ variable was dichotomized in the present study, a procedure adopted by other investigators $^{48}$. The analysis of sub-scores was not considered in this study ${ }^{14)}$.

Differences were found in level of anxiety depending on years of study. Halboulb et $a l^{21)}$ 
Table 3 Results of Poisson regression model, adjusted and not adjusted for WHOQOL-bref outcome, and demographic, school, anxiety and sleep variables among students at a private Brazilian university.

\begin{tabular}{|c|c|c|c|c|c|c|}
\hline \multirow{2}{*}{ Variables } & \multicolumn{2}{|c|}{ WHOQOL } & \multicolumn{2}{|c|}{ Bivariate } & \multicolumn{2}{|c|}{ Multivariate } \\
\hline & $\begin{array}{c}>14 \\
\mathrm{n}(\%)\end{array}$ & $\begin{array}{c}\leq 14 \\
\mathrm{n}(\%)\end{array}$ & $\begin{array}{l}\text { Unadjusted } \\
\text { p-value }\end{array}$ & $\begin{array}{c}\mathrm{PR} \\
(95 \% \mathrm{CI})\end{array}$ & $\begin{array}{c}\text { Adjusted } \\
\text { p-value }\end{array}$ & $\begin{array}{c}\text { PR } \\
(95 \% \mathrm{CI})\end{array}$ \\
\hline \multicolumn{7}{|l|}{ Age } \\
\hline$\leq 21$ & $18(50.0)$ & $58(55.2)$ & & 1.00 & - & - \\
\hline$>21$ & $18(50.0)$ & $47(44.8)$ & 0.589 & $\begin{array}{c}0.95 \\
(0.78-1.15)\end{array}$ & - & - \\
\hline \multicolumn{7}{|l|}{ Sex } \\
\hline Male & $11(30.6)$ & $15(14.3)$ & & 1.00 & & 1.00 \\
\hline Female & $25(69.4)$ & $90(85.7)$ & 0.045 & $\begin{array}{c}1.35 \\
(0.78-2.34)\end{array}$ & 0.063 & $\begin{array}{c}0.74 \\
(0.54-1.02)\end{array}$ \\
\hline \multicolumn{7}{|l|}{ Years of study } \\
\hline 2nd-3rd & $25(69.4)$ & $53(50.5)$ & & 1.00 & & 1.00 \\
\hline 1st & $2(5.6)$ & $14(13.3)$ & 0.039 & $\begin{array}{c}1.29 \\
(1.01-1.64)\end{array}$ & 0.131 & $\begin{array}{c}1.17 \\
(0.95-1.44)\end{array}$ \\
\hline 4 th-5th & $9(25.0)$ & $38(36.2)$ & 0.099 & $\begin{array}{c}1.19 \\
(0.97-1.46)\end{array}$ & 0.503 & $\begin{array}{c}1.07 \\
(0.88-1.30)\end{array}$ \\
\hline \multicolumn{7}{|l|}{ Shift } \\
\hline Morning & $24(66.7)$ & $64(61.0)$ & & 1.00 & - & - \\
\hline Night & $12(33.3)$ & $41(39.0)$ & 0.533 & $\begin{array}{c}1.06 \\
(0.88-1.29)\end{array}$ & - & - \\
\hline \multicolumn{7}{|c|}{ STAI-S (quartiles) } \\
\hline $31-42.5$ & $17(47.2)$ & $18(17.1)$ & & 1.00 & & 1.00 \\
\hline $42.6-49$ & $11(30.6)$ & $28(26.7)$ & 0.083 & $\begin{array}{c}1.40 \\
(0.96-2.04)\end{array}$ & 0.107 & $\begin{array}{c}1.34 \\
(0.94-1.91)\end{array}$ \\
\hline $49.1-56.5$ & $7(19.4)$ & $25(23.8)$ & 0.027 & $\begin{array}{c}1.52 \\
(1.05-2.20)\end{array}$ & 0.068 & $\begin{array}{c}1.41 \\
(0.97-2.04)\end{array}$ \\
\hline $56.6-76$ & $1(2.8)$ & $34(32.4)$ & $<0.001$ & $\begin{array}{c}1.89 \\
(1.36-2.62)\end{array}$ & 0.034 & $\begin{array}{c}1.46 \\
(1.03-2.06)\end{array}$ \\
\hline \multicolumn{7}{|c|}{$S A Q$ (quartiles) } \\
\hline $27-38$ & $15(41.7)$ & $21(20.0)$ & & 1.00 & & 1.00 \\
\hline $38.1-45$ & $15(41.7)$ & $21(20.0)$ & 1.000 & $\begin{array}{c}1.00 \\
(0.68-1.49)\end{array}$ & 0.701 & $\begin{array}{c}0.93 \\
(0.63-1.36)\end{array}$ \\
\hline $45.1-52$ & $5(13.9)$ & $31(29.5)$ & 0.013 & $\begin{array}{c}1.48 \\
(1.09-2.00)\end{array}$ & 0.070 & $\begin{array}{c}1.32 \\
(0.98-1.78)\end{array}$ \\
\hline $52.1-64$ & $1(2.7)$ & $32(30.5)$ & $<0.001$ & $\begin{array}{c}1.66 \\
(1.25-2.20)\end{array}$ & 0.040 & $\begin{array}{c}1.39 \\
(1.02-1.90)\end{array}$ \\
\hline
\end{tabular}

Note: p-values estimated by Poisson regression with robust and adjusted variance.

PR: prevalence ratio. 
indicated that stress increased significantly as the educational level increased, corroborating the findings of Igbal et al. ${ }^{23)}$ with medical undergraduate students. In contrast, Alonso et $a .^{1)}$ revealed that university entrance was stressful.

Benavente et $a .^{9}{ }^{9}$ analyzed 151 undergraduate nursing students and identified loss of quality of sleep in the sample. The onset of the university pathway was associated with sleep problems arising from changes in routine due to an increase in the amount of time required to assimilate large volumes of information. Academics from other courses also had worse QOL scores during the early years of their studies ${ }^{23)}$.

In the present study, the shift worked showed a significant association with global QOL. It should be borne in mind that those who study during the morning shift have to start early, which may have affected sleep. In addition, those who study at night usually work concomitantly. An extended awake time, together with the demands of academic activities, may also affect sleep duration ${ }^{28)}$.

Amadeu and Justi $^{2)}$, in 2017, evaluated QOL and the socioeconomic circumstances in 150 undergraduate and graduate students of dentistry at a public university in the State of São Paulo. They found that the domain with the best evaluation was social relations (D3), followed by psychological (D2), with the worse values for physical (D1). This ordering follows the same pattern as the findings in the current research.

The Poisson regression model, which estimates rate ratios, was selected as it is recognized as robust for cross-sectional studies ${ }^{6}$.

This study had a number of limitations related to its cross-sectional design. This meant that the identification of causal relationships was impaired, as data collection on both exposures and outcomes was performed at a single moment in time ${ }^{8)}$.

The majority of the students analyzed showed some degree of anxiety and sleep disorders, with this negatively impacting their QOL. Actions aimed at promoting health in the academic environment are desirable, as is identifying factors that might adversely affect $\mathrm{it}^{50)}$. Some earlier studies reported that training in stress prevention was associated with a reduction in stress among undergraduate students $^{25,30,511}$. Such strategies should be incorporated into health profession training programs, and include mindfulness-based intervention, relaxation, and meditation ${ }^{30,49}$.

The present results indicate that identification of potential factors in decreased QOL can help prevent this occurring by providing guidance to dental students in their decision making. Such guidance would increase awareness of the importance of regulated and rehabilitated sleep; incentivize engagement in physical activities and social interactions; reduce consumption of alcohol and sleeping medication; and decrease anxiety levels during classes; all of this acting to increase wellbeing during the academic period.

\section{Conflict of Interest}

The authors declare no conflict of interest related to this manuscript.

\section{References}

1) Alonso J, Mortier P, Auerbach RP, Bruffaerts R, Vilagut G, Cuijpers P, Demyttenaere K, Ebert DD, Ennis E, Gutiérrez-García RA, Green JG, Hasking P, Lochner C, Nock MK, PinderAmaker S, Sampson NA, Zaslavsky AM, Kessler RC; WHO WMH-ICS Collaborators (2018) Severe role impairment associated with mental disorders: Results of the WHO World Mental Health Surveys International College Student Project. Depress Anxiety 35:802-814.

2) Amadeu JR, Justi MM (2017) Qualidade de vida de estudantes de graduação e pós-graduação em Odontologia. Arch Health Invest 6: 540-544.

3) Associação Nacional dos Dirigentes das Instituições Federais de Ensino Superior (ANDIFES). Fórum Nacional de Pró-Reitores de Assuntos Comunitários e Estudantis (2011) Perfil socioeconômico e cultural dos estudantes de graduação das universidades federais brasileiras, FONAPRACE, Brasília. 
4) Associação Nacional dos Dirigentes das Instituições Federais de Ensino Superior (ANDIFES). Fórum Nacional de Pró-Reitores de Assuntos Comunitários e Estudantis (2014) IV Pesquisa do perfil socioeconômico e cultural dos estudantes de graduação das instituições federais de ensino superior brasileiras, FONAPRACE, Brasília.

5) Bampi LNS, Baraldi S, Guilhem D, Araújo MP, Campos ACO (2013) The quality of life of medical students at the University of Brasilia, Brazil. Rev Bras Educ Med 37:217-225.

6) Barros AJ, Hirakata VN (2003) Alternatives for logistic regression in cross-sectional studies: an empirical comparison of models that directly estimate the prevalence ratio. BMC Med Res Methodol 3:21.

7) Basudan S, Binanzan N, Alhassan A (2017) Depression, anxiety and stress in dental students. Int J Med Educ 8:179-186.

8) Belbasis L, Bellou V (2018) Introduction to epidemiological studies. Methods Mol Biol 1793:1-6.

9) Benavente SBT, da Silva RM, Higash AB, Guido LA, Costa ALS (2014) Influence of stress factors and sociodemographic characteristics on the sleep quality of nursing students. Rev Esc Enferm USP 48:512-518.

10) Biaggio AMB, Natalicio L, Spielberger CD (1977) Desenvolvimento da forma experimental em português do Inventário de Ansiedade Traço-Estado (IDATE) de Spielberger. Arq Bras Psicol 19:31-44.

11) Brenneisen Mayer F, Souza Santos I, Silveira PS, Itaqui Lopes MH, de Souza AR, Campos EP, de Abreu BA, Hoffman II I, Magalhães CR, Lima MC, Almeida R, Spinardi M, Tempski P (2016) Factors associated to depression and anxiety in medical students: a multicenter study. BMC Med Educ 16:282.

12) Cattell RB, Scheier IH (1961) The meaning and measurement of neuroticism and anxiety, Ronald Oxford, England.

13) Cesta A, Moldofsky H, Sammut C (1996) The University of Toronto Sleep Assessment Questionnaire (SAQ). Sleep Res 25:486.

14) Cesta A, Moldofsky H, Sammut C (1999) The sensitivity and specificity of the Sleep Assessment Questionnaire (SAQ) as a measure of non-restorative sleep. Sleep Med Rev 99:1-4.

15) Chernomas WM, Shapiro C (2013) Stress, depression, and anxiety among undergraduate nursing students. Int J Nurs Educ Scholars 10:255-266.

16) Corrêa CC, Oliveira FK, Pizzamiglio DS, Ortolan EVP, Weber SAT (2017) Qualidade de sono em estudantes de medicina: comparação das diferentes fases do curso. J Bras Pneumol 43:285-289.

17) Elani HW, Allison PJ, Kumar RA, Mancini L, Lambrou A, Bedos C (2014) A systematic review of stress in dental students. J Dent Educ 78:226-242.

18) Fleck MPA, Leal OF, Louzada S, Xavier M, Chachamovich E, Vieira G, Santos L, Pinzon V (1999) Desenvolvimento da versão em português do instrumento de avaliação de qualidade de vida da organização mundial da saúde (WHOQOL-100). Rev Bras Psiquiatr 21: 19-28.

19) Fleck MPA, Louzada S, Xavier M, Chachamovich E, Vieira, G, Santos L, Pinzon V (2000) Aplicação da versão em português do instrumento abreviado de avaliação da qualidade de vida WHOQOL-bref. Rev Saude Publica 34: 178-183.

20) Ghodasara SL, Davidson MA, Reich MS, Savoie CV, Rodgers SM (2011) Assessing student mental health at the Vanderbilt University School of Medicine. Acad Med 86:116-121.

21) Halboub E, Alhajj MN, AlKhairat AM, Sahaqi AM, Quadri MFA (2018) Perceived stress among undergraduate dental students in relation to gender, clinical training and academic performance. Acta Stomatol Croat 52:37-45.

22) Ibrahim AK, Kelly SJ, Adams CE, Glazebrook C (2013) A systematic review of studies of depression prevalence in university students. J Psychiatr Res 47:391-400.

23) Iqbal S, Gupta S, Venkatarao E (2015) Stress, anxiety and depression among medical undergraduate students and their socio-demographic correlates. Indian J Med Res 141: 354-357.

24) Kang JH, Chen SC (2009) Effects of an irregular bedtime schedule on sleep quality, daytime sleepiness, and fatigue among university students in Taiwan. BMC Public Health 9:248.

25) Kuhlmann SM, Huss M, Bürger A, Hammerle F (2016) Coping with stress in medical students: results of a randomized controlled trial using a mindfulness-based stress prevention training (MediMind) in Germany. BMC Med Educ 16:316.

26) Lima PF, Medeiros ALD, Araujo JF (2002) Sleep-wake pattern of medical students: early versus late class starting time. Braz J Med Biol Res 35:1373-1377.

27) Lucchetti G, Damiano RF, DiLalla LF, Lucchetti ALG, Moutinho ILD, da Silva Ezequiel O, Kevin Dorsey J (2018) Crosscultural differences in mental health, quality of life, empathy, and burnout between US and Brazilian medical students. Acad Psychiatry 42:62-67. 
28) Maier SRO, Mattos M (2016) O trabalhar e o estudar no contexto universitário: uma abordagem com trabalhadores-estudantes. Saúde (Santa Maria) 42:179-185.

29) Marques DR, Meia-Via AMS, da Silva CF, Gomes AA (2017) Associations between sleep quality and domains of quality of life in a nonclinical sample: results from higher education students. Sleep Health 3:348-356.

30) McConville J, McAleer R, Hahne A (2017) Mindfulness training for health profession students-the effect of mindfulness training on psychological well-being, learning and clinical performance of health professional students: a systematic review of randomized and nonrandomized controlled trials. Explore (NY) 13:26-45.

31) Medeiros ALD, Mendes DBF, Lima PF, Araujo JF (2001) The relationships between sleepwake cycle and academic performance in medical students. Biol Rhythm Res 32: 263-270.

32) Milojevich HM, Lukowski AF (2016) Sleep and mental health in undergraduate students with generally healthy sleep habits. PLoS One 11: e0156372.

33) Ortuño-Sierra J, García-Velasco L, Inchausti F, Debbané M, Fonseca-Pedrero E (2016) New approaches on the study of the psychometric properties of the STAI. Actas Esp Psiquiatr 44: 83-92.

34) Paiva T, Gaspar T, Matos MG (2015) Sleep deprivation in adolescents: correlations with health complaints and health-related quality of life. Sleep Med 16:521-527.

35) Pascotto AC, Santos BRM (2013) Assessing sleep quality in health occupations students. J Health Sci Inst 31:306-310.

36) Peltzer K, Pengpid S (2015) Nocturnal sleep problems among university students from 26 countries. Sleep Breath 19:499-508.

37) Pesqueira AA, Zuim PR, Monteiro DR, Ribeiro PP, Garcia AR (2010) Relationship between psychological factores and symptoms of TDM in university undergraduate students. Acta Odontol Latinoam 23:182-187.

38) Pöhlmann K, Jonas I, Ruf S, Haerzer W (2005) Stress, burnout and health in the clinical period of dental education. EurJ Dent Educ 9: 78-84.

39) Qamar K, Khan NS, Bashir Kiani MR (2015) Factors associated with stress among medical students. J Pak Med Assoc 65:753-755.

40) Ratnani IJ, Vala AU, Panchal BN, Tiwari DS, Karambelkar SS, Sojitra MG, Nagori NN (2017) Association of social anxiety disorder with depression and quality of life among medical undergraduate students. J Family
Med Prim Care 6:243-248.

41) Samaranayake CB, Arroll B, Fernando AT 3rd (2014) Sleep disorders, depression, anxiety and satisfaction with life among young adults: a survey of university students in Auckland, New Zealand. N Z Med J 127:13-22.

42) Sanders AE, Lushington K (2002) Effect of perceived stress on student performance in dental school. J Dent Educ 66:75-81.

43) Spielberger CD, Gorsuch RL, Lushene RE (1970) Manual for the State-Trait Anxiety Inventory, Palo Alto, Consulting Psychologist Press.

44) Tavernier R, Willoughby T (2014) Sleep problems: predictor or outcome of media use among emerging adults at university? J Sleep Res 23:389-396.

45) Taylor DJ, Bramoweth AD, Grieser EA, Tatum JI, Roane BM (2013) Epidemiology of insomnia in college students: relationship with mental health, quality of life, and substance use difficulties. Behav Ther 44:339-348.

46) The WHOQOL Group 1998 (1998) Development of the World Health Organization WHOQOL-BREF quality of life assessment. Psychol Med 28:551-558.

47) The WHOQOL Group 1998 (1998) The World Health Organization quality of life assessment (WHOQOL): development and general psychometric properties. Soc Sci Med 46:1569-1585.

48) Unger ER, Nisenbaum R, Moldofsky H, Cesta A, Sammut C, Reyes M, Reeves WC (2004) Sleep assessment in a population-based study of chronic fatigue syndrome. BMC Neurol 4:6.

49) Van der Riet $P$, Levett-Jones $T$, Aquino-Russell C (2018) The effectiveness of mindfulness meditation for nurses and nursing students: an integrated literature review. Nurse Educ Today 65:201-211.

50) Winwood PC, Winefield AH, Lushington K (2008) The role of occupational stress in the maladaptive use of alcohol by dentists: A study of South Australian general dental practitioners. Aust Dent J 48:102-109.

51) Yusoff M (2014) Interventions on medical students' psychological health: a meta-analysis. J Taibah Univ Med Sci 9:1-13.

Correspondence:

Dr. Rafaela Scariot

School of Health Sciences, Universidade Positivo,

Rua Prof. Pedro Viriato Parigot de

Souza, 5300

81280-330 Curitiba, Paraná, Brazil

E-mail: rafaela_scariot@yahoo.com.br 